\title{
POROUS HA/ALUMINA COMPOSITES INTENDED FOR BONE-TISSUE ENGINEERING
}

\author{
POROZNI HA/ALUMINIJEVI KOMPOZITI, NAMENJENI ZA \\ NADOMESTNO UPORABO PRI KOSTNEM TKIVU
}

\author{
Eva Bartonickova, Jan Vojtisek, Jakub Tkacz, Jaromir Porizka, Jiri Masilko, \\ Miroslava Moncekova, Ladislav Parizek \\ Brno University of Technology, Faculty of Chemistry, Materials Research Centre, Purkynova 464/118, 612 00 Brno, Czech Republic \\ bartonickova@fch.vutbr.cz
}

Prejem rokopisa - received: 2016-07-15; sprejem za objavo - accepted for publication: 2016-11-24

doi:10.17222/mit.2016.191

\begin{abstract}
Ceramic biomaterials based on hydroxyapatite (HA) or alumina have been intensively studied due to their load-bearing applications in the bone-tissue replacement/reconstruction and dental applications. Here we present a study of the preparation and properties of HA/alumina (HA/Al) composites with a targeted porosity. The HA powder used for the composite's preparation was synthetized via a precipitation method under a variety of $\mathrm{pH}$ values. The resulting powders were verified with XRD, Raman and FTIR analyses. The particle size was assessed via SEM and laser diffraction. The as-prepared HA nanopowder and alumina powder (median $3 \mu \mathrm{m})$ were homogenously mixed having a composition of HA/Alumina $=90 / 10(w / w)$. A suspension with $65 \%$ mass fraction of the powders was properly mixed and, with the help of foaming agents, it was foamed in situ. The behavior under an increasing temperature was studied, using a heating microscope and dried foams were sintered under determined temperatures. The final sintered foams were examined in vitro in a synthetic body fluid, which predicted the behavior of bone implants in vivo. The behavior of the treated samples was studied with SEM. The newly formed HA composites were confronted with $\mathrm{Ca}^{2+}$ and $\mathrm{PO}_{4}{ }^{3-}$ contents in the applied body-fluid solution.

Keywords: hydroxyapatite/ $\mathrm{Al}_{2} \mathrm{O}_{3}$ composite, ceramic scaffolds, in-vitro bioactivity, SEM
\end{abstract}

Keramični biomateriali na osnovi hidroksiapatitov (HA) ali aluminijevega oksida so bili sistematsko preiskovani zaradi njihove najboljše nadomestne vloge pri nadomeščanju kostnega tkiva/rekonstrukciji in pri zobnih vsadkih. Predstavljena je študija priprave in lastnosti kompozitov HA / aluminijevega oksida (HA / Al) s ciljem preizkusa poroznosti. HA prah, ki se uporablja za pripravo kompozitov, smo sintetizirali po postopku obarjanja pri različnih pH-vrednostih. Dobljene praške smo preverili z XRD-, Raman in FTIR-analizo. Velikost delcev je bila ocenjena s pomočjo SEM in z lasersko difrakcijo. Pripravljen nanoprašek (HA) in aluminijev oksid v prahu (median $3 \mu \mathrm{m}$ ) sta bila homogeno premešana v mešanico HA/aliminij 90/10 (w/w). Suspenzija s 65 masnimi \% praškov je bila ustrezno mešana in s pomočjo penil spenjena in situ. Raziskovali smo obnašanje v okviru naraščajoče temperature, uporabo pod ogrevanim mikroskopom in suhe pene so bile sintrane pri določenih temperaturah. Končne sintrane pene so bile pregledane in vitro kot sintetične tekočine, ki so napovedale obnašanje kostnih vsadkov in vivo. Obnašanje obdelanih vzorcev smo preučevali s SEM. Pri vstavitvi oz. stiku s telesno tekočino so bili na novo oblikovani HA v stiku $\mathrm{z} \mathrm{Ca}{ }^{2+}$ in vsebino $\mathrm{PO}_{4}{ }^{3-}$.

Ključne besede: hidroksiapatit/ $\mathrm{AI}_{2} \mathrm{O}_{3}$ kompozit, keramična ogrodja, bioaktivnost in vitro, SEM

\section{INTRODUCTION}

The load-bearing system of humans, although it is very durable, can sometimes lose a vital part due to injuries, illnesses or wear. In this case, it is necessary to replace the original tissue with suitable implants. The first attempts to replace bone tissues is dated back to the early years before Christ, but the intensive development of this research area underwent a boom in the second half of the $20^{\text {th }}$ century. Nowadays, the $2^{\text {nd }}$ and $3^{\text {rd }}$ generations of biomaterials are in progress. Hydroxyapatite belongs to biocompatible materials with osteoconductive and osteointegrating properties and exhibits chemical and physical analogies to the minerals present in human bones and teeth. ${ }^{1-2}$ Although HA exhibits excellent bio-properties, its clinical application failed due to poor mechanical properties, a long remodeling time and a relatively slow rate of osteointegration. ${ }^{3}$ So, the reinforcement of HA become part of the research. In recent works, HA ceramics were reinforced with metals, polymers or toughened zirconia ceramics. ${ }^{4-6}$

A synthesis of HA at the nanoscale has been studied very often. There are many ways of how to prepare a powder with targeted properties (i.e., at least one dimension under $100 \mathrm{~nm}$ ). The wet procedures under the conventional or non-conventional conditions, especially precipitation, hydrothermal, sonochemical or microwave treatments, are used most commonly. ${ }^{7-9}$ The sol-gel technique of an HA synthesis exhibits a high level of HA-powder homogeneity; nevertheless, the secondary formed calcium oxide represents extraction and biocompatibility problems. $^{8}$ The variability of the preparation of a ceramic foam is extremely wide. An in-situ foaming procedure favors scaffold-preparation procedures due to the possibility of controlling the porosity with an exact diameter, in comparison with the 
widely used replica method using a polymeric sponge. ${ }^{10-11}$

The composite preparation was based on the same procedures. The HA matrix was reinforced with ceramic-oxide constituents such as zirconia, titania, silica, yttria, bioglass or alumina. ${ }^{3,6,12-18}$ Alumina oxide is a cost-effective and well-accessible option for enhancing HA properties, especially the mechanical properties. The mechanical strength of a porous human bone is in a range of 2-12 $\mathrm{MPa} .{ }^{19}$ The reported values for pure HA are in a range of $1.2-16 \mathrm{MPa}$, depending on the foaming process. ${ }^{20}$ A positive alumina contribution to the mechanical strength was recently reported by I. Sopyan et al. ${ }^{21}$ and L. L. Wang et al. ${ }^{17,22}$

The presented paper introduces an overall scaffold preparation based on an hydroxyapatite matrix reinforced with an alumina-oxide addition. The physical properties and in-vitro behavior of the final porous scaffolds are presented.

\section{EXPERIMENTAL PART}

\subsection{Synthesis of the hydroxyapatite powder}

The hydroxyapatite powder was synthetized via a simple precipitation method from calcium nitrate $\left(\mathrm{Ca}\left(\mathrm{NO}_{3}\right)_{2} .4 \mathrm{H}_{2} \mathrm{O}\right.$; puriss; LachNer; the Czech Republic) and phosphoric acid $\left(\mathrm{H}_{3} \mathrm{PO}_{4}\right.$; puriss; Penta; Czech Republic) precursors. The syntheses was carried out under laboratory conditions and via the reaction mechanism given in Equation (1):

$$
\begin{aligned}
& 10 \mathrm{Ca}\left(\mathrm{NO}_{3}\right)_{2}+6 \mathrm{H}_{3} \mathrm{PO}_{4}+20 \mathrm{NH}_{4} \mathrm{OH} \rightarrow \\
\rightarrow & \mathrm{Ca}_{10}\left(\mathrm{PO}_{4}\right)_{6}(\mathrm{OH})_{2}+20 \mathrm{NH}_{4 \mathrm{~N}} \mathrm{O}_{3}+18 \mathrm{H}_{2} \mathrm{O}
\end{aligned}
$$

Aqueous solutions of precursors $\left(\mathrm{Ca}^{2+}\right.$ concentration - $1.3 \mathrm{~mol} / \mathrm{L} ; \mathrm{PO}_{4}{ }^{3-}$ concentration $-1 \mathrm{~mol} / \mathrm{L}$ ) were simultaneously added dropwise into an aqueous solution with a controlled $\mathrm{pH}$ value. The $\mathrm{pH}$ value was varied from 1 to 9.6 and adjusted with an addition of ammonium hydroxide $\left(\mathrm{NH}_{4} \mathrm{OH}\right.$; puriss; LachNer, the Czech Republic). To assess the reaction kinetics, turbidimetric measurements of the formed precipitates (2100Q Hach) combined with the reaction-yield determination were conducted. The precipitated products were centrifugally separated, washed and dried at $80{ }^{\circ} \mathrm{C}$. The prepared powders were analyzed in the terms of phase and chemical compositions and morphology (an EMPYREAN Panalytical diffractometer in the central focusing arrangement using $\mathrm{Co}-K_{\alpha}$ radiation, the Netherlands; a FTIR spectrometer Nicolet iS50 Thermo Fisher Scientific, U.S.A.; and an EVO CS10 ZEISS electron microscope equipped with an energy-dispersive analyzer with an Oxford X-Max $80 \mathrm{~mm}^{2}$ detector in the back-scattering mode, respectively).

\subsection{Scaffold fabrication and characterization}

The synthetized HA powder and commercial alumina powder (Nabalox 325; Nabaltec AG, Germany) were properly mixed at a HA/alumina ratio of 90:10. The aqueous suspensions containing $55 \%$ mass fraction of the HA solid loading and $65 \%$ mass fraction of the composite solid loading were homogenously mixed to avoid the unfavorable agglomeration. The foaming agent (Schäumungsmittel Zschimmer\&Scharz GmbH \& Co, Germany) was added to the prepared suspensions with a concentration of $0.25 \%$ mass fraction. The given concentrations of the solid loading and the foaming agent were previously experimentally determined. After the agent addition, the mixing rate of the magnetic stirrer was immediately accelerated to initialize the foaming process (up to $1000 \mathrm{~min}^{-1}$ ). The foamed suspensions were cast in an open aluminium-foil mould with dimensions of $(1 \times 1 \times 1) \mathrm{cm}$ and $(2 \times 2 \times 2) \mathrm{cm}$ for apatiteforming-ability tests and determination of the mechanical properties, respectively. To avoid the formation of unfavourable cracks, the drying process was carried out in several steps - at $50{ }^{\circ} \mathrm{C}$ for $4 \mathrm{~h} ; 80{ }^{\circ} \mathrm{C}$ for $10 \mathrm{~h}$ and, finally, $105^{\circ} \mathrm{C}$ for $3 \mathrm{~h}$. Dried samples were demoulded and heated to $600{ }^{\circ} \mathrm{C}$ for an organic-species removal and to $1250{ }^{\circ} \mathrm{C}$ (the temperature determined with a heating microscopy analysis (EM 201 Leitz, Germany) to carry out the foam consolidation. The porosity evaluation was examined using mercury intrusion porosimetry (Poremaster Quantachrome, U.S.A.), an image analysis (Stemi 508 ZEISS, Austria; processed via ImageJ software) and Archimedes' bulk-density determination (ISO EN 5017 2013). The mechanical properties of porous scaffolds were calculated from stress-strain curves using a universal mechanical testing machine (5985C INSTRON, U.S.).

\subsection{Apatite-forming-ability testing}

The behavior of the samples in the human body was simulated with a stability test. The samples were thoroughly immersed in a modified simulated body liquid (SBF) prepared via Kokubo's procedure ${ }^{23}$ and soaked for $(7,14$ and 28$) \mathrm{d}$ in an incubator chamber at $37^{\circ} \mathrm{C}$. The surfaces of the treated samples were observed

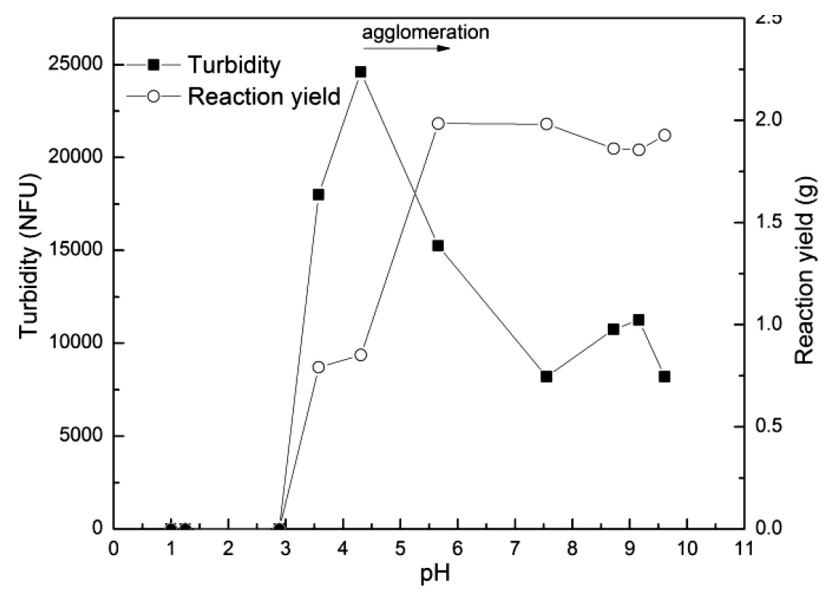

Figure 1: Turbidimetry and reaction yield as a function of $\mathrm{pH}$ 


\section{E. BARTONICKOVA et al.: POROUS HA/ALUMINA COMPOSITES INTENDED FOR BONE-TISSUE ENGINEERING}

with SEM. The concentrations of $\mathrm{Ca}^{2+}$ and $\mathrm{PO}_{4}{ }^{3-}$ in pure and treated SBFs were analyzed using ion chromatography (Metrosep C4 15/4.0 Metrohm, Switzerland) and ICP-OES (Ultima 2 Jobin Yvon Technology, France).

\section{RESULTS AND DISCUSSION}

\subsection{Hydroxyapatite characterization and in-situ foam- ing}

The hydroxyapatite formation was studied by means of reaction kinetics using turbidity measurements. Figure 1 describes the yield and turbidity of the reaction product as a function of $\mathrm{pH}$. An increase in $\mathrm{pH}$ from 1 to 6 increased the turbidity values and the product yield. The maximum turbidity was reached at a $\mathrm{pH}$ of 4 and corresponded to the colloidal character of the nucleated and grown HA particles. After this value, the precipitated particles started to flocculate and the suspension became unstable. Large-sized particles started to agglomerate and the sediment corresponded with lower turbidity values, whereas the yield of the reaction was unchanged. ${ }^{8,24}$ The high level of agglomeration was confirmed with a morphology analysis and laser-diffraction measurements (Figure 2). The phase purity and crystallinity of the prepared powders are given in Figure 3. A strong dependence of the precipitation reaction on the $\mathrm{pH}$ is obvious (Figure 3 and Table 1). A pH below 7
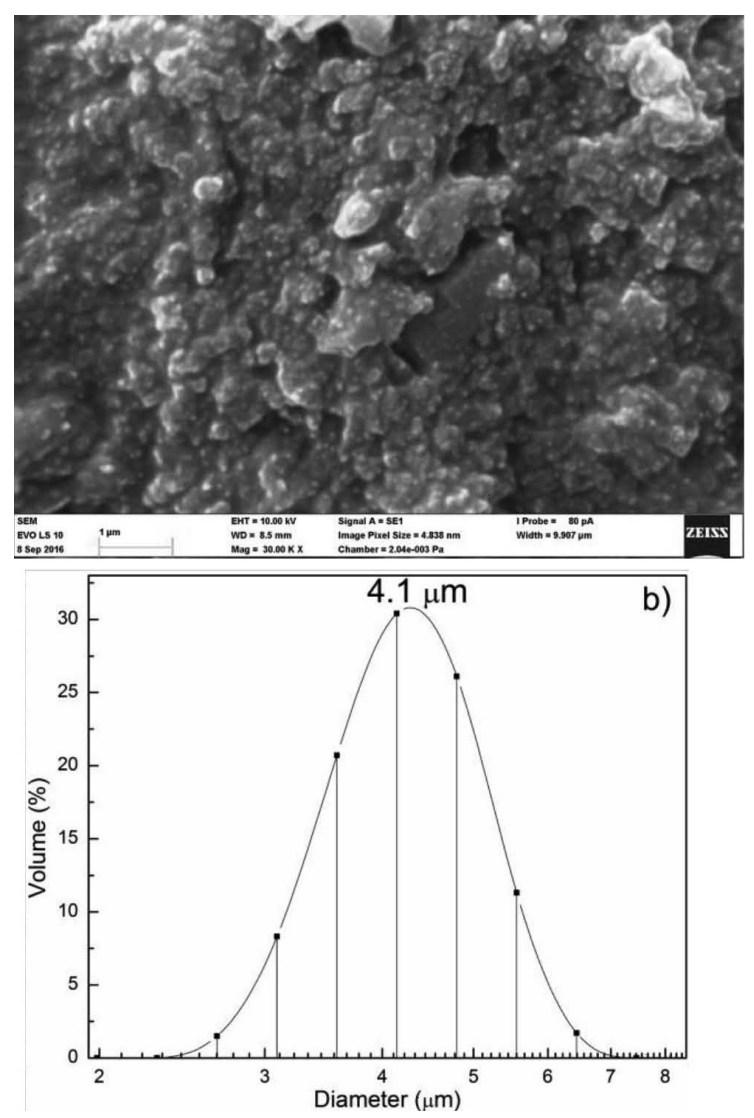

Figure 2: Synthetized hydroxyapatite powder: a) morphology, b) particle-size distribution

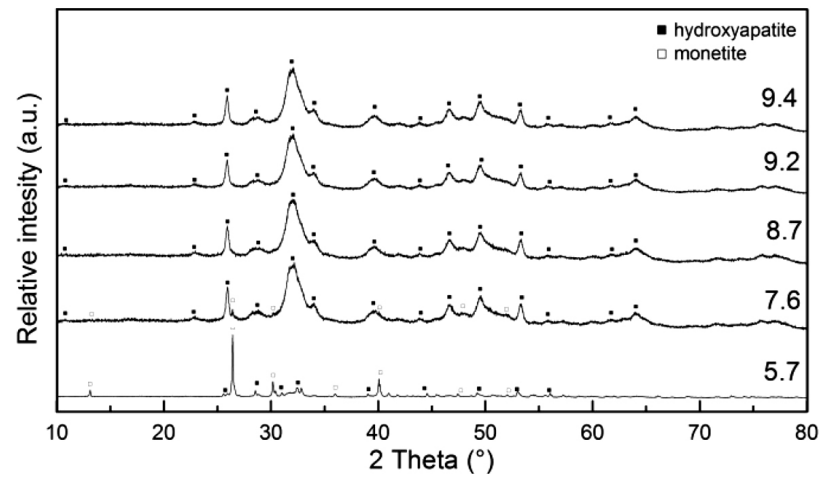

Figure 3: Dependence of the HA-product phase purity on the $\mathrm{pH}$ value

exhibits a heterogeneous system based on hydroxyapatite and monetite (ICCD 01-089-6438 and ICCD 01-0700359, resp.). Similar kinetics was observed in several works where a phase-pure HA powder with nanodimensions, but agglomerated, was also synthetized. , $25-26^{-26}$ Based on the results summarized above, the optimum $\mathrm{pH}$ of the reaction was set to 8.7. The HA powder used for the in-situ foaming was successfully and repeatedly prepared on large scale, with a $100 \%$ phase purity and the mean agglomerate size of about $4 \mu \mathrm{m}$.

Table 1: Phase analysis of the synthetized HA powders under different $\mathrm{pH}$ values

\begin{tabular}{|c|c|c|}
\hline $\mathrm{pH}$ & $\begin{array}{c}\text { Monetite }-\mathrm{CaHPO}_{4} \\
(w / \%)\end{array}$ & $\begin{array}{c}\text { Hydroxyapatite }- \\
\mathrm{Ca}\left(\mathrm{PO}_{4}\right)_{3}(\mathrm{OH})(w / \%)\end{array}$ \\
\hline 4.5 & 100 & 0 \\
\hline 5.7 & 87 & 13 \\
\hline 6.6 & 18 & 82 \\
\hline 8.7 & 0 & 100 \\
\hline 9,2 & 0 & 100 \\
\hline 9.4 & 0 & 100 \\
\hline
\end{tabular}

A significant factor for the successful foaming of the prepared suspensions was the stability of the foam

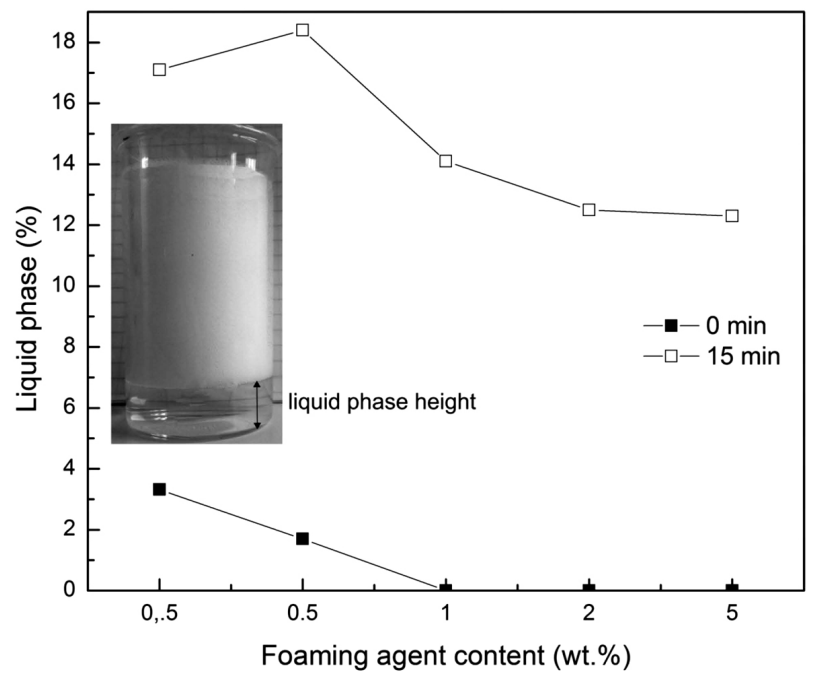

Figure 4: Foam-stability test in terms of time dependence 


\section{E. BARTONICKOVA et al.: POROUS HA/ALUMINA COMPOSITES INTENDED FOR BONE-TISSUE ENGINEERING}

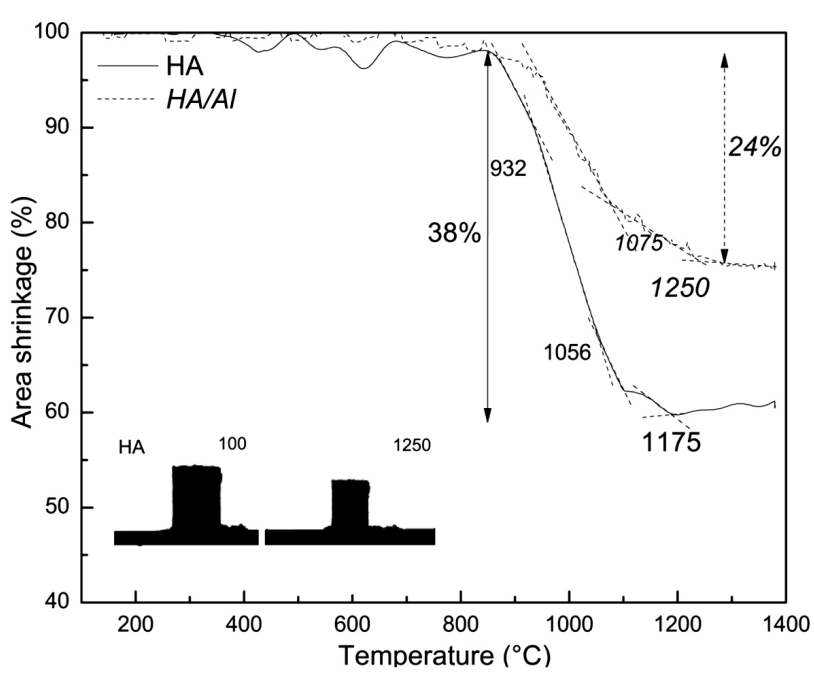

Figure 5: Sintering study provided with a heating microscope analysis

prepared without a ceramic powder. This stability was studied with respect to the content of the foaming agent (Figure 4) and the time to the foam structure's collapse. The $0.25 \%$ mass-fraction content of the foaming agent was determined as the optimum value. P. Ptáček et al. ${ }^{27}$ recently published a paper, in which an aqueous/detergent-based foam was also studied in terms of the time-stability dependence and similar experimental data was observed.

The sintering behavior of the pure powder and composite is shown in Figure 5. The area shrinkage was found to be $38 \%$ for HA and $24 \%$ for the HA/Al composite. The optimum sintering temperature for HA and $\mathrm{HA} / \mathrm{Al}$ sintering was determined, according to the experimental data, to be $1250{ }^{\circ} \mathrm{C}$. The consolidation of the closely packed particles seemed to be finished according to the sintering curve (Figure 5). The phase analysis of the sintered samples showed a decomposition of the HA structure to several apatite forms above the temperature of $1150{ }^{\circ} \mathrm{C}^{18}$ (tricalcium phosphate, trical-

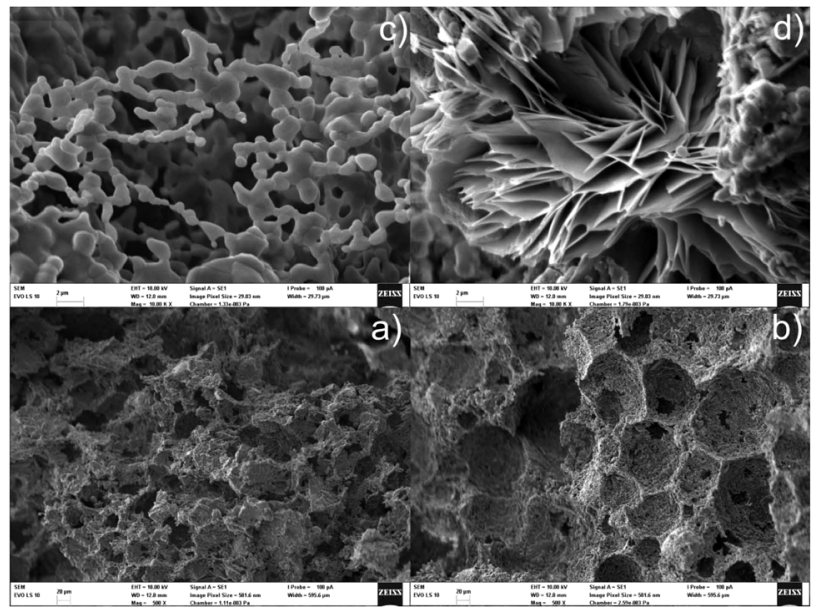

Figure 6: Microstructures of the HA and composite scaffolds: a) HA scaffold, b) HA/Alumina scaffold, c) HA scaffold - a detail, d) hibonite structure observed in the HA/Alumina scaffold cium hydrogen diphosphate, tetracalcium tetraphosphate and residual $\mathrm{HA}$ ). In the case of the $\mathrm{HA} / \mathrm{Al}$ composite sample, the formation of tricalcium phosphate and the $\mathrm{Ca}-\mathrm{Al}$ phase was observed. It was reported that $\alpha$ - and $\beta$-tricalcium phosphates are more biodegradable apatite forms in comparison with the HA structure ${ }^{28}$, which is closely connected with the chosen temperature of the sintering discussed above. The newly formed $\mathrm{Ca}-\mathrm{Al}$ structure of the composite samples was positively identified as hibonite $\mathrm{CaAl}_{12} \mathrm{O}_{19}$ (ICCD 01-076-0665) with a platelet hexagonal arrangement, which is shown, in detail, in Figure 6d.

L.-P. Li et al. ${ }^{29}$, M. H. Ghazanfari et al. ${ }^{16}$ and B. Basar et al. ${ }^{30}$ also observed the formation of the $\mathrm{Ca}-\mathrm{Al}$ phase in $\mathrm{HA} / \mathrm{Al}$ composites with similar particle morphologies at temperatures of 1350,1250 and $1100{ }^{\circ} \mathrm{C}$, respectively.

The structures of the scaffolds prepared from the pure hydroxyapatite powder and composite powder using in-situ foaming are given in Figure 6. The alumina contribution is clearly visible; the composite foam has a ball-shaped structure (Figure 6b) resulting from the foaming process, with a pore diameter of around $60 \mu \mathrm{m}$ (obtained with the image analysis). The microstructure is apparently similar to those presented by P. Ptáček et al. ${ }^{27}$, where the aqueous-surfactant system was also used. On the other hand, the observed microstructures of the HA foams (Figure 6a and $\mathbf{6 c}$ ) are more heterogeneous, having even smaller pores (of around $28 \mu \mathrm{m}$ according to the image analysis) than the composite one. The presence of hibonite was also confirmed with the EDS and SEM analysis (Figure 6d). The HA scaffolds provided significantly higher mechanical-strength values (see the embedded image in Figure 7). These findings indicate a low degree of foam consolidation due to the alumina part with a higher sintering-temperature region. Similar values of the mechanical strength and the corresponding

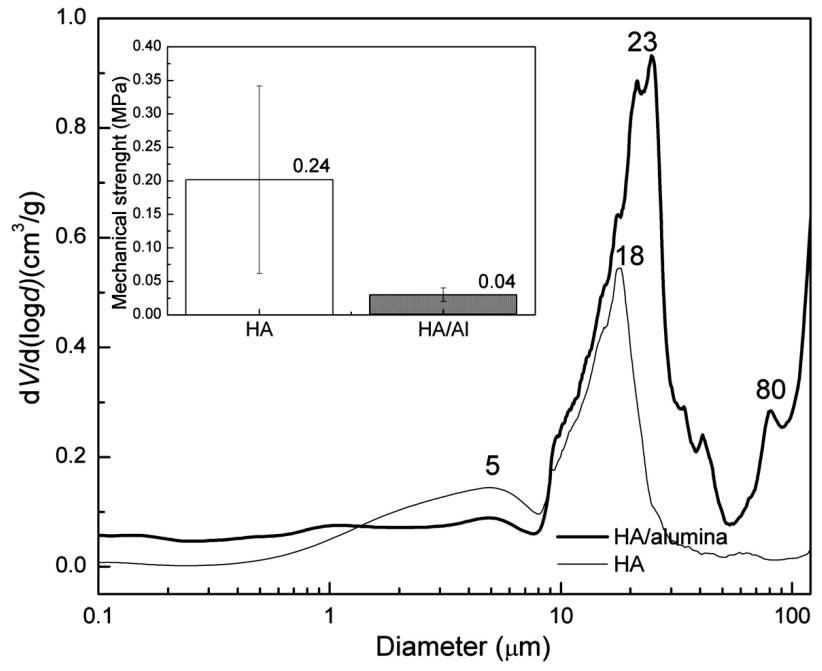

Figure 7: Porosity determination and mechanical strength (embedded) of HA and HA/Alumina scaffolds 


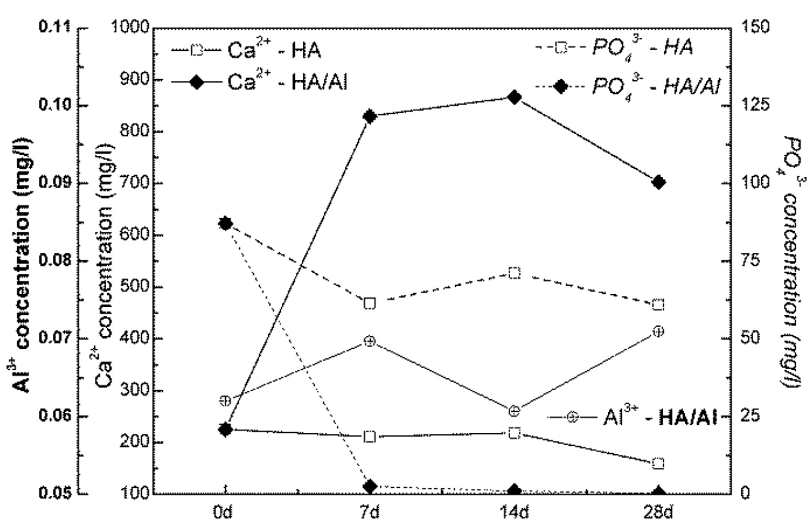

Figure 8: Cation concentration in the applied synthetic body fluid, time to release dependence

phase composition were also achieved by M. H. Ghazanfari et al. ${ }^{16}$

The total porosities determined with Archimedes' method were (45.9 and 63.1) \% of materials theorethical density for HA and the HA/alumina composite, respectively. Pore-size distributions for both of the scaffolds are given in Figure 7, reflecting the effect of the alumina addition on the pore-structure evolution. The performed analysis showed a possible collapse of the HA/Al foam structure during an $\mathrm{Hg}$ intrusion, visible as an increasing tendency of the curve above $100 \mu \mathrm{m}$ or the presence of significantly large pores. Figure 7 (the embedded image) shows the mechanical properties of the prepared scaffolds. The measured values are in the equipment limits, so the relative deviation is considerable. The maximum mechanical strength reached for the pure HA structure was 0.2 MPa. The expected enhancement of the alumina addition in the mechanical properties was not confirmed. The higher strength also reflected the obtained porosity values, i.e., the HA/alumina composites showed higher total porosities with a lower sintering degree than the pure HA ones.

\subsection{In-vitro behavior - the apatite-forming ability}

Figures 8 and 9 summarize the in-vitro testing of the prepared scaffolds. The synthetic body fluid, prepared by T. Kokubo ${ }^{23}$, simulated the bloody-plasma environment in the human body. In Figure 8, the concentrations of the most important ion species, $\mathrm{Ca}^{2+}, \mathrm{Al}^{3+}$ and $\mathrm{PO}_{4}{ }^{3-}$, are

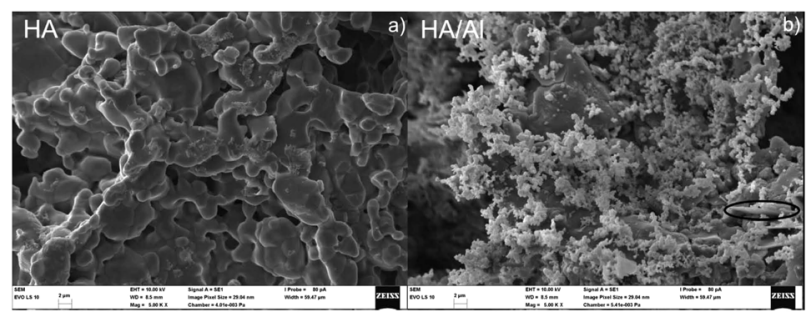

Figure 9: In-vitro evaluation of the treated HA and HA/Al scaffolds in SBF, SEM analysis after $28 \mathrm{~d}$ of treatment given. The pure HA scaffolds exhibited the expected behavior; the gradual consumption of both of the ions corresponded to the formation of the new HA on the scaffold surface (Figure 9). The ability of a Ca-apatite formation on the surface was frequently reported in the past. $^{31-32}$ Otherwise the reactivity of the HA/Al composite in the SBF environment was slightly different. As could be seen from Figure 8, the $\mathrm{PO}_{4}{ }^{3-}$ ions were totally consumed within $28 \mathrm{~d}$; on the other hand, the $\mathrm{Ca}^{2+}$ and $\mathrm{Al}^{3+}$ cation concentration had an increasing tendency. The newly formed phase practically covered the composite scaffold surfaces (Figure 9). The performed EDS analysis could not exactly distinguish between the formations of the $\mathrm{Ca}$ - or Al-bonded apatite structures. The probability of the formation of both phases is almost certain. X. Chatzistavrou et al. ${ }^{33}$ described the mechanism of the $\mathrm{Ca}-\mathrm{Al}$ apatite formation on a HA/Al composite surface according to the reaction scheme in Equation (2), which is in good agreement with our data:

$$
\mathrm{Al}-\mathrm{OH}+\mathrm{H}_{2} \mathrm{PO}_{4}{ }^{2-} \rightarrow \mathrm{Al}-\mathrm{O}-\mathrm{PO}_{3}^{-}+\mathrm{OH}^{-}
$$

\section{CONCLUSION}

In this work, a synthesis of the nanosized phase of a pure hydroxyapapatite powder was successfully performed on a large scale. Porous scaffolds based on the as-synthetized hydroxyapatite and supplied alumina powders were fabricated using the in-situ foaming process. The prepared HA scaffolds exhibited significantly better mechanical properties, with the total porosity of about $46 \%$, than the HA/Al scaffold with a porosity of about $64 \%$. In-vitro testing of both scaffolds confirmed an appropriate apatite-forming ability. The HA/Al composite was significantly more covered with the newly formed phase than the pure HA ones. A study of the nucleation and growth mechanism of $\mathrm{Ca}-\mathrm{Al}$ apatite is in progress.

\section{Acknowledgement}

The paper was supported by the project Materials Research Centre at FCH BUT - Sustainability and Development, REG LO1211, with a financial support from the National Programme for Sustainability I (the Ministry of Education, Youth and Sports).

\section{REFERENCES}

${ }^{1}$ G. Tripathi, B. Basu, A porous hydroxyapatite scaffold for bone tissue engineering: Physico-mechanical and biological evaluations, Ceram. Int., 38 (2012) 1, 341-349, doi:10.1016/j.ceramint.2011. 07.012

${ }^{2}$ G. Radha, S. Balakumar, B. Venkatesan, E. Vellaichamy, Evaluation of hemocompatibility and in vitro immersion on microwave-assisted hydroxyapatite-alumina nanocomposites, Mater. Sci. Eng., C 50 (2015), 143-150, doi:10.1016/j.msec.2015.01.054 


\section{MATERIALI IN TEHNOLOGIJE/MATERIALS AND TECHNOLOGY (1967-2017) - 50 LET/50 YEARS}

\section{E. BARTONICKOVA et al.: POROUS HA/ALUMINA COMPOSITES INTENDED FOR BONE-TISSUE ENGINEERING}

${ }^{3}$ S. Khorsand, M. H. Fathi, S. Salehi, S. Amirkhanlou, Hydroxyapatite/alumina nanocrystalline composite powders synthesized by sol-gel process for biomedical applications, Int. J. Min. Met. Mater., 21 (2014) 10, 1033-1036, doi:10.1007/s12613-014-1005-7

${ }^{4}$ H. Itokawa, T. Hiraide, M. Moriya, M. Fujimoto, G. Nagashima, R. Suzuki, T. Fujimoto, A 12 month in vivo study on the response of bone to a hydroxyapatite-polymethylmethacrylate cranioplasty composite, Biomaterials, 28 (2007) 33, 4922-4927, doi:10.1016/j.biomaterials.2007.08.001

${ }^{5}$ K. R. Mohamed, H. H. Beherei, G. T. El Bassyouni, N. El Mahallawy, Fabrication and mechanical evaluation of hydroxyapatite/oxide nano-composite materials, Materials Science and Engineering, C 33 (2013) 7, 4126-4132, doi:10.1016/j.msec.2013.05.059

${ }^{6}$ W. Kantana, P. Jarupoom, K. Pengpat, S. Eitssayeam, T. Tunkasiri, G. Rujijanagul, Properties of hydroxyapatite/zirconium oxide nanocomposites, Ceram. Int. 39, Suppl. 1 (2013), S379-S382, doi:10.1016/j.ceramint.2012.10.098

${ }^{7}$ I. Mobasherpour, M. S. Heshajin, A. Kazemzadeh, M. Zakeri, Synthesis of nanocrystalline hydroxyapatite by using precipitation method, J. Alloys Compd., 430 (2007) 1-2, 330-333, doi:10.1016/ j.jallcom.2006.05.018

${ }^{8}$ M. Sadat-Shojai, M.-T. Khorasani, E. Dinpanah-Khoshdargi, A. Jamshidi, Synthesis methods for nanosized hydroxyapatite with diverse structures, Acta Biomater., 9 (2013) 8, 7591-7621, doi:10.1016/j.actbio.2013.04.012

${ }^{9}$ E. K. Girija, G. S. Kumar, A. Thamizhavel, Y. Yokogawa, S. N. Kalkura, Role of material processing on the thermal stability and sinterability of nanocrystalline hydroxyapatite, Powder Technol., 225 (2012), 190-195, doi:10.1016/j.powtec.2012.04.007

${ }^{10}$ A. R. Studart, U. T. Gonzenbach, E. Tervoort, L. J. Gauckler, Processing Routes to Macroporous Ceramics: A Review, J. Am. Ceram. Soc., 89 (2006) 6, 1771-1789, doi:10.1111/j.1551-2916.2006. 01044.x

${ }^{11}$ M. D. M. Innocentini, P. Sepulveda, V. R. Salvini, V. C. Pandolfelli, J. R. Coury, Permeability and Structure of Cellular Ceramics: A Comparison between Two Preparation Techniques, J. Am. Ceram. Soc., 81 (1998) 12, 3349-3352, doi:10.1111/j.1151-2916.1998. tb02782.X

${ }^{12}$ J. Y. Han, Z. T. Yu, L. Zhou, Hydroxyapatite/titania composite bioactivity coating processed by sol-gel method, Appl. Surf. Sci., 255 (2008) 2, 455-458, doi:10.1016/j.apsusc.2008.06.072

${ }^{13}$ S. M. Latifi, M. H. Fathi, M. A. Golozar, Preparation and characterisation of bioactive hydroxyapatite-silica composite nanopowders via sol-gel method for medical applications, Adv. Appl. Ceram., 110 (2011) 1, 8-14, doi:10.1179/174367510x12753884125325

${ }^{14}$ S. Salehi, M. H. Fathi, Fabrication and characterization of sol-gel derived hydroxyapatite/zirconia composite nanopowders with various yttria contents, Ceram. Int., 36 (2010) 5, 1659-1667, doi:10.1016/j.ceramint.2010.02.045

${ }^{15}$ R. Ravarian, F. Moztarzadeh, M. S. Hashjin, S. M. Rabiee, P. Khoshakhlagh, M. Tahriri, Synthesis, characterization and bioactivity investigation of bioglass/hydroxyapatite composite, Ceram. Int., 36 (2010) 1, 291-297, doi:10.1016/j.ceramint.2009.09.016

${ }^{16}$ S. M. H. Ghazanfari, A. Zamanian, Phase transformation, microstructural and mechanical properties of hydroxyapatite/alumina nanocomposite scaffolds produced by freeze casting, Ceram. Int., 39 (2013) 8, 9835-9844, doi:10.1016/j.ceramint.2013.05.096

${ }^{17}$ L.-1. Wang, X.-F. Wang, X. Ding, J.-F. Zhu, Sintering Behavior and Property of Bioglass Modified HA-A12O3 Composite, Sci. Sinter., 44 (2012) 3, 265-270, doi:10.2298/sos $1203265 \mathrm{w}$
${ }^{18}$ J. Li, B. Fartash, L. Hermansson, Hydroxyapatite alumina composites and bone-bonding, Biomaterials, 16 (1995) 5, 417-422, doi:10.1016/0142-9612(95)98860-g

${ }^{19}$ L. L. Hench, J. Wilson, An Introduction to Bioceramics, World Scientific, Singapore, 1993

${ }^{20} \mathrm{H}$. Yoshikawa, A. Myoui, Bone tissue engineering with porous hydroxyapatite ceramics, Journal of Artificial Organs, 8 (2005) 3, 131-136, doi:10.1007/s10047-005-0292-1

${ }^{21}$ I. Sopyan, A. Fadli, M. Mel, Effect of hydroxyapatite and tricalcium phosphate addition on protein foaming-consolidation porous alumina, J. Porous Mater., 19 (2012) 5, 733-743, doi:10.1007/ s10934-011-9525-2

${ }^{22}$ L.-L. Wang, X.-F. Wang, X. Ding, H.-T. Jiang, Preparation of HA-Bioglass-A12O3 Biological Composite, Mater. Manuf. Processes, 28 (2013) 9, 980-983, doi:10.1080/10426914.2012. 709339

${ }^{23}$ T. Kokubo, H. Takadama, How useful is SBF in predicting in vivo bone bioactivity?, Biomaterials, 27 (2006) 15, 2907-2915, doi:10.1016/j.biomaterials.2006.01.017

${ }^{24} \mathrm{H}$. Lange, Comparative test of methods to determine particle size and particle-size distribution in the submicron rang, Part. Part. Syst. Charact., 12 (1995) 3, 148-157, doi:10.1002/ppsc.19950120307

${ }^{25}$ S. S. A. Abidi, Q. Murtaza, Synthesis and Characterization of NanoHydroxyapatite Powder Using Wet Chemical Precipitation Reaction, Journal of Materials Science \& Technology, 30 (2014) 4, 307-310, doi:10.1016/j.jmst.2013.10.011

${ }^{26}$ E. Kramer, J. Podurgiel, M. Wei, Control of hydroxyapatite nanoparticle morphology using wet synthesis techniques: Reactant addition rate effects, Mater. Lett., 131 (2014), 145-147, doi:10.1016/j.matlet.2014.05.105

${ }^{27}$ P. Ptáček, K. Lang, F. Šoukal, T. Opravil, L. Tvrdík, R. Novotný, Preparation and properties of nanostructured ceramic foam from kaolinite, Powder Technol., 253 (2014), 29-34, doi:10.1016/ j.powtec.2013.10.026

${ }^{28}$ G. Hannink, J. J. C. Arts, Bioresorbability, porosity and mechanical strength of bone substitutes: What is optimal for bone regeneration?, Injury-International Journal of the Care of the Injured, 42 (2011), S22-S25, doi:10.1016/j.injury.2011.06.008

${ }^{29}$ L.-P. Li, Y. Yan, X.-Z. Fan, Z.-H. Hu, C.-Y. Zhao, Low-temperature synthesis of calcium-hexaluminate/magnesium-aluminum spinel composite ceramics, J. Eur. Ceram. Soc., 35 (2015) 10, 2923-2931, doi:10.1016/j.jeurceramsoc.2015.03.041

${ }^{30}$ B. Basar, A. Tezcaner, D. Keskin, Z. Evis, Synthesis, phase transitions and cellular biocompatibility of nanophase alumina-hydroxyapatite composites, Adv. Appl. Ceram., 110 (2011) 4, 238-243, doi:10.1179/1743676111y.0000000012

${ }^{31}$ S. Saber-Samandari, S. Kiyazar, J. Aghazadeh, A. Sadeghi, In vitro evaluation for apatite-forming ability of cellulose-based nanocomposite scaffolds for bone tissue engineering, Int. J. Biol. Macromol., 86 (2016), 434-442, doi:10.1016/j.ijbiomac.2016.01.102

${ }^{32}$ G. Thrivikraman, G. Madras, B. Basu, In vitro/In vivo assessment and mechanisms of toxicity of bioceramic materials and its wear particulates, RSC Advances, 4 (2014) 25, 12763-12781, doi:10.1039/c3ra44483j

${ }^{33}$ X. Chatzistavrou, N. Kantiranis, E. Kontonasaki, K. Chrissafis, L. Papadopoulou, P. Koidis, A. R. Boccaccini, K. M. Paraskevopoulos, Thermal analysis and in vitro bioactivity of bioactive glass-alumina composites, Mater. Charact., 62 (2011) 1, 118-129, doi:10.1016/ j.matchar.2010.11.008 